\title{
Article
}

\section{Pocket Guide for the Assessment and Treatment of Eating Disorders}

Wright, Karen Margaret

Available at http://clok.uclan.ac.uk/29385/

Wright, Karen Margaret ORCID: 0000-0003-0693-7294 (2019) Pocket Guide for the Assessment and Treatment of Eating Disorders. Journal Of Mental Health, 28 (5). p. 578. ISSN 0963-8237

It is advisable to refer to the publisher's version if you intend to cite from the work. http://dx.doi.org/10.1080/09638237.2019.1644495

For more information about UCLan's research in this area go to

http://www.uclan.ac.uk/researchgroups/ and search for <name of research Group>.

For information about Research generally at UCLan please go to http://www.uclan.ac.uk/research/

All outputs in CLoK are protected by Intellectual Property Rights law, including Copyright law. Copyright, IPR and Moral Rights for the works on this site are retained by the individual authors and/or other copyright owners. Terms and conditions for use of this material are defined in the policies page.

\section{CLoK}

Central Lancashire online Knowledge www.clok.uclan.ac.uk

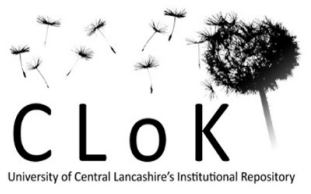




\title{
Pocket Guide for the Assessment and Treatment of Eating Disor- ders
}

\author{
K. WRIGHT
}

[AQ0]

Karen M. Wright ${ }^{1}$

1. School of Nursing, University of Central Lancashire, Preston, UK

Email: kmwright1@uclan.ac.uk

Received: 2019-06-26

Accepted: 2019-07-10

This text is written for and by psychiatrists in the main, all of the authors being based in California. However, if you are searching for an excellent summary text offering vital diagnostic information and treatment options then this is your text in a nutshell, as these contributors are all well positioned to provide that. Having said that, I was pleased to see the first three words of the foreword are "Providing care for...", since people experiencing eating disorders will almost certainly need long term and complex care by a multidisciplinary team. So, whilst the language and the approach are medicalised and may, at times, appear to be in conflict with a person-centred approach, the book provides an evidence-based and comprehensive mini-text which forms a very useful foundation for the knowledge required to care for this population.

I would suggest that some of the directness of this text is due to its concise and condensed approach to the subject matter; it is called a "pocket" guide and it did, indeed, slide neatly into my back pocket. Hence, multiple perspectives, whether they be alternative clinical perspectives, international or cultural positions on the assessment and treatment of eating disorders, are lacking: a "Californian lens" is adopted throughout.

A standard model is adopted for each of the seven chapters, using 14 pre-set headings, starting with introduction and diagnostic checklist, and finishing with common outcomes and complications, further reading and references. This makes for easy navigation through the essential information. "The basics" chapter is followed by the remaining six chapters, each related to a diagnostic label, for example, "Anorexia Nervosa", "Binge-Eating Disorder", etc.

It would be very easy to find fault with such a concise text, in terms of what is NOT included. My initial impression was that this book lacked the therapeutic and person-centred focus that would enable me to care for (i.e. nurse) individuals of all ages who experienced eating disorder. BUT, this text still has a huge amount of utility. Readers need to be mindful that there are pointers to additional and further reading, and that some clinicians working in this field, for example, dieticians, family therapists and, to an extent, nurses, may initially feel poorly served by this book. As a nurse and psychotherapist, I would suggest that you suspend your disbelief, and be more "solution-focussed", appreciating the high level of intelligence contained within its pages.

If we are to work respectfully and reciprocally across disciplines then clinicians of all kinds need to get a grip on the essential information contained in this easy-to-read and concise text.

Karen M. WrightSchool of Nursing, University of Central Lancashire, Preston, UKkmwright1@uclan.ac.uk[AQ1]

\section{AUthor QUERIES}


Query: AQ0: Please review the table of contributors below and confirm that the first and last names are structured correctly and that the authors are listed in the correct order of contribution. This check is to ensure that your names will appear correctly online and when the article is indexed.

Sequence Prefix Given name(s) Surname Suffix

1

Karen $\mathrm{M}$.

Wright

Response: Ok

Response: Ok

Query: AQ1: The corresponding author email address has been imported from CATS. Please revise if incorrect.

Response: Ok

Response: Ok

\section{Author Approve Comments}

Author: I am happy with this. Karen 